\title{
МОДЕЛИРОВАНИЕ ВЗАИМОДЕЙСТВИЯ 7-МЕТИЛГУАНИНА С ТРНК-ГУАНИНТРАНСГЛИКОЗИЛАЗОЙ
}

\author{
В.А. Винник', С.В. Пушкарев², В.К. Швядас ${ }^{2,3}$, Д.К. Нилов \\ ${ }^{1}$ Московский государственный университет им. М.В. Ломоносова, факультет \\ фундаментальной медицины, 119192, Россия, Москва, Ломоносовский просп., д. 27, корп. 1. \\ ${ }^{2}$ Московский государственный университет им. М.В. Ломоносова, факультет биоинженерии и \\ биоинформатики, 119991, Россия, Москва, Ленинские горы, д. 1, стр. 73. \\ ${ }^{3}$ Московский государственный университет им. М.В. Ломоносова, \\ Научно-исследовательский институт физико-химической биологии им. А.Н. Белозерского, \\ 119991, Россия, Москва, Ленинские горы, д. 1, стр. 40.
}

DOI: 10.19163/MedChemRussia2021-2021-391

E-mail:valeriavinnik71@gmail.com

7-Метилгуанин является природным метаболитом нуклеиновых кислот. Данное соединение обладает противоопухолевой активностью, предположительно за счет ингибирования белка репарации ДНК поли(ADP-рибозо)полимеразы-1 (ПАРП-1) [1,2]. Также 7-метилгуанин подавляет активность TPHК-гуанинтрансгликозилазы (ТГТ), катализирующей замену гуанина в первой позиции антикодона ТРНК на кьюин [3]. Недавно было обнаружено, что данная модификация ТРНК важна для пролиферации и миграции раковых клеток [4]. Это позволяет рассматривать ТГТ в качестве дополнительной мишени (наряду с ПАРП-1) для противоопухолевого действия 7-метилгуанина.

Задачей представленной работы являлось создание молекулярной модели комплекса 7-метилгуанина с ТГТ. Модель ТГТ была сконструирована на основе кристаллической структуры 6h45. Докинг 7-метилгуанина в активный центр проводили с помощью программы Lead Finder (http://www.moltech. $\mathrm{ru}$. Уравновешивание и последующую симуляцию молекулярной динамики полученного комплекса проводили с помощью пакета Amber20 (https:// ambermd.org). В результате было показано, что 7-метилгуанин занимает позицию субстрата ТГТ - кьюина и образует устойчивые взаимодействия с аминокислотными остатками Phe109, Asp159, Gly229 и Met259. Сравнение активных центров ПАРП-1 и ТГТ позволяет предложить для синтеза более селективные производные 7-метилгуанина.

Работа поддержана Российским научным фондом (грант № 19-74-10072).

\section{Литература}

[1] Д.К. Нилов, В.И. Тараров, А.В. Куликов, А.Л. Захаренко, И.В. Гущина, С.Н. Михайлов, О.И. Лаврик, В.К. Швядас, Acta Naturae. 2016, 8, 120-128.

[2] D. Nilov, N. Maluchenko, T. Kurgina, S. Pushkarev, A. Lys, M. Kutuzov, N. Gerasimova, A. Feofanov, V. Švedas, O. Lavrik, and V.M. Studitsky, Int. J. Mol. Sci. 2020, 21, 2159.

[3] W.R. Farkas, K.B. Jacobson, and Katze J.R., Biochim. Biophys. Acta. 1984, 781, 64-75.

[4] J. Zhang, R. Lu, Y. Zhang, Ż. Matuszek, W. Zhang, Y. Xia, T. Pan, and J. Sun, Cancers. 2020, 12, 628. 